\title{
Pengembangan Modul Pembelajaran Tematik Berbasis Saintifik dengan Penguatan Karakter Mandiri Subtema Perpindahan Kalor Kelas V SDN Gadungan Wates Kediri
}

\author{
Sahara Thasyia Nirasmala, Lilik Bintartik*, Suhel Madyono \\ Universitas Negeri Malang, Jl. Semarang No. 5 Malang, Jawa Timur, Indonesia \\ *Penulis korespondensi, Surel: lilik.bintartik@fip.um.ac.id
}

Paper received: 1-4-2021; revised: 22-4-2021; accepted: 29-4-2021

\begin{abstract}
Research and development of scientific-based thematic learning modules with the strengthening of independent character in the heat transfer sub-theme are done as a solution for the learning independence of fifth-grade students of SDN Gadungan. Modules are prepared using a scientific approach in which there are practicums as student media so that they can develop concepts by conducting experiments. So that the combination of the use of modules, scientific approaches, and heat transfer practicums will form the strengthening of the independent character of students.
\end{abstract}

Keywords: learning module; scientific approaches; independence character

\begin{abstract}
Abstrak
Penelitian dan pengembangan modul pembelajaran tematik berbasis saintifik dengan penguatan karakter mandiri pada subtema perpindahan kalor ini dilakukan sebagai solusi untuk kemandirian belajar siswa kelas V SDN Gadungan. Modul disusun dengan menggunakan pendekatan saintifik yang didalamnya terdapat praktikum sebagai media siswa agar dapat membangun konsep dengan melakukan percobaan. Sehingga kombinasi penggunan modul, pendekatan saintifik, dan praktikum perpindahan kalor akan membentuk penguatan karakter mandiri pada diri siswa.
\end{abstract}

Kata kunci: modul pembelajaran; pendekatan saintifik; karakter mandiri

\section{Pendahuluan}

Pembelajaran di Sekolah Dasar (SD) saat ini menggunakan pembelajaran tematik. Maka dari itu dituntut adanya bahan pembelajaran yang mengaitkan mata pelajaran satu dengan lainnya yang dikuatkan dengan pendekatan ilmiah (saintifik). Hal tersebut senada dengan yang tertulis dalam Permendikbud Nomor 22 Tahun 2016 bahwa prinsip yang digunakan berubah dari pembelajaran tekstual menjadi pembelajaran dengan menggunakan pendekatan saintifik. Langkah-langkah pendekatan saintifik menurut Daryanto (2014) meliputi mengamati, menanya, menalar, mencoba, serta mengkomunikasikan. Dari tahapan-tahapan di atas dapat dilihat bahwa pendekatan saintifik bertujuan agar siswa terlibat aktif secara fisik \& mental dalam pembelajaran.

Salah satu cara untuk menstimulasi siswa agar mampu belajar secara saintifik adalah dengan menggunakan bahan pembelajaran yang menumbuhkan rasa ingin tahu siswa yang dapat dipelajari dan dipahami sendiri oleh siswa. Bahan pembelajaran yang dapat dikembangkan adalah modul. Modul adalah bahan ajar cetak yang dibuat agar siswa dapat belajar secara mandiri. Mandiri adalah sikap dimana seseorang dapat melaksanakan tugasnya sendiri tanpa tergantung kepada orang lain. 
Hasil wawancara dan observasi diketahui bahwa siswa SDN Gadungan Wates Kabupaten Kediri kegiatan belajarnya masih dominan mendengarkan penjelasan dari guru. Selain itu buku yang ada belum mendukung terjadinya pembelajaran secara saintifik. Oleh karena itu, dibutuhkan bahan ajar yang dapat dipahami sendiri sehingga dapat menumbuhkan karakter mandiri siswa, dan juga dapat mendukung terjadinya pembelajaran secara saintifik. Sehingga solusi yang tepat untuk masalah tersebut adalah dikembangkannya Modul Pembelajaran Tematik Berbasis Saintifik dengan Penguatan Karakter Mandiri pada Subtema Perpindahan Kalor di Kelas V SDN Gadungan Wates Kabupaten Kediri. Hal ini didukung dari hasil penelitian yang dilakukan sebelumnya yang dilakukan oleh Oktafiyani (2016) yaitu pengembangan modul IPA berbasis kemandirian belajar siswa kelas IV SD. Penelitian tersebut menyatakan bahwa modul yang dikembangkan dapat digunakan siswa untuk mempelajari materi energi panas secara mandiri tanpa bantuan dari guru.

\section{Metode}

Produk ini dikembangkan dengan menggunakan metode Research and Development $(R$ $\& D)$ menurut Borg and Gall yang dikutip dari Sugiyono (2014). Metode ini diwujudkan dalam 10 langkah penelitian pengembangan yaitu 1) potensi dan masalah;2) pengumpulan data; 3) desain produk; 4) validasi produk; 5) revisi produk; 6) ujicoba produk; 7) revisi produk; 8) ujicoba pemakaian; 9) revisi produk; dan 10) produksi massal.

Jenis data yang digunakan adalah data kuantitatif dan kualitatif yang diperoleh dari hasil validasi ahli materi, ahli bahan ajar, guru sebagai pengguna, serta respon siswa terhadap produk yang dikembangkan. Teknik pengumpulan data menggunakan teknik wawancara, observasi, dokumentasi, catatan lapangan serta angket. Angket validasi oleh ahli materi, ahli bahan ajar pengguna menggunakan Skala Likert. Skala Likert dapat dilihat pada Tabel 1.

Tabel 1. Skor Likert

\begin{tabular}{ll}
\cline { 2 - 2 } Kriteria & Skor yang diperoleh \\
\hline Sangat Baik & 4 \\
Baik & 3 \\
Cukup & 2 \\
Kurang Baik & 1 \\
\hline
\end{tabular}

Sumber : Sugiyono (2014)

Sedangkan untuk respon siswa terhadap modul pembelajaran menggunakan Skala Guttman. Menurut Sugiyono (2014) skala Guttman adalah skala yang digunakan untuk mendapat jawaban tegas dari petanyaan yang diajukan. Respon siswa digunakan untuk memperoleh data kemenarikan produk dan kemandirian siswa.

Tabel 2. Skala Guttman

Sumber : Sugiyono (2014)

\begin{tabular}{ll}
\hline Alternatif Jawaban & Skor \\
\hline Ya & 1 \\
Tidak & 0 \\
\hline
\end{tabular}

Data yang diperoleh kemudian diolah dengan menggunakan rumus validasi yang dirujuk dari Akbar (2017) sebagai berikut :

$\mathrm{Vah}=\frac{\mathrm{Tse}}{\mathrm{Tsh}} \times 100 \%$ 
Keterangan :

Vah : Validasi Ahli

Tse : Total skor yang akan dicapai

Tsh : Total skor yang diharapkan

Selanjutnya hasil perhitungan dikategorisasikan seperti yang terdapat pada Tabel 3

Tabel 3 Kategori Hasil Validasi, Kemenarikan, dan Kemandirian

\begin{tabular}{lll}
\hline $\begin{array}{l}\text { Tingkat pencapaian } \\
\text { (\%) }\end{array}$ & Kategori & Keputusan uji \\
\hline $85,01-100,00$ & $\begin{array}{l}\text { Sangat valid/menarik/ } \\
\text { mandiri }\end{array}$ & Dapat digunakan tanpa revisi \\
$70,01-85,00$ & $\begin{array}{l}\text { Cukup valid/menarik/ } \\
\text { mandiri }\end{array}$ & $\begin{array}{l}\text { Dapat digunakan, namun perlu revisi } \\
\text { kecil }\end{array}$ \\
$50,01-70,00$ & $\begin{array}{l}\text { Kurang valid/menarik/ } \\
\text { mandiri }\end{array}$ & $\begin{array}{l}\text { Boleh digunakan, namun dengan revisi } \\
\text { besar } \\
\text { Tidak valid/menarik/ } \\
\text { mandiri }\end{array}$ \\
& & Tidak boleh digunakan \\
\hline
\end{tabular}

Sumber : Akbar (2017)

Berdasarkan kriteria validasi, kemenarikan dan kemandirian pada tabel 3, modul dapat digunakan jika persentase tingkat pencapaiannya minimal 70,1\%. Jika masih dibawah 70,1\% harus dilakukan revisi besar terlebih dahulu.

\section{Hasil dan Pembahasan}

Modul yang dikembangkan terdiri dari tiga bagian utama yaitu bagian pendahuluan, inti, serta penutup. Bagian pendahuluan terdiri dari halaman sampul, kata pengantar, daftar isi, petunjuk penggunaan, kompetensi inti, kompetensi dasar. Bagian inti terdiri dari judul, tujuan pembelajaran, kegiatan belajar siswa, rangkuman, evaluasi. Dan bagian penutup terdiri dari atas glosarium, evaluasi akhir, daftar pustaka.

Modul telah divalidasi oleh ahli bahan ajar Bapak Arda Purnama Putra, S.Pd., M.Pd , ahli materi yaitu Ibu Esti Untari, S.Pd., M.Pd, serta pengguna yaitu Ibu Sri Muji Rahayu, S.Pd. dari hasil validasi oleh ketiga validator modul memperoleh kategori sangat valid untuk digunakan oleh siswa. Hasil validasi tersebut masing-masing akan dipaparkan pada Tabel 4, Tabel 5 dan Tabel 6 berikut.

Tabel 4. Hasil Validasi Ahli Bahan Ajar

\begin{tabular}{cllll}
\hline No. & Aspek & Nilai & Persentase (\%) & Kategori \\
\hline A. & Penyajian Modul & & & \\
1. & Kelengkapan bagian modul & 4 & 100 & Sangat Valid \\
2. & Bagian awal modul & 4 & 100 & Sangat Valid \\
3. & Bagian inti modul & 4 & 100 & Sangat Valid \\
4. & Bagian akhir modul & 4 & 100 & Sangat Valid \\
\hline B. & Tampilan Modul & & & \\
5. & Konsistensi & 4 & 100 & Sangat Valid \\
6. & Format & 4 & 100 & Sangat Valid \\
7. & Organisasi & 4 & 100 & Sangat Valid \\
8. & Daya tarik & 4 & 100 & Sangat Valid \\
9. & Ukuran huruf & 4 & 100 & Sangat Valid \\
10. & Penggunaan spasi kosong & 4 & 100 & \\
\hline C. & Karakteristik Modul & & & Sangat Valid \\
11. & Selfintructional (a) & 4 & 100 &
\end{tabular}




\begin{tabular}{lllll}
\hline No. & Aspek & Nilai & Persentase (\%) & Kategori \\
\hline & Self intructional (b) & 4 & 100 & Sangat Valid \\
12. & Stand alone & 4 & 100 & Sangat Valid \\
13. & User friendly & 4 & 100 & Sangat Valid \\
\hline & Jumlah & 56 & 1400 & - \\
\hline & Rata-Rata & 4 & 100 & Sangat Valid \\
\hline & Keputusan Uji & Dapat digunakan tanpa revisi \\
\hline
\end{tabular}

Berdasarkan hasil validasi pada Tabel 4, didapatkan keputusan uji bahwa modul pembelajaran tematik berbasis saintifik dengan penguatan karakter mandiri pada subtema perpindahan kalor yang dikembangkan layak diujicobakan tanpa revisi. Komentar dan saran ahli bahan ajar terhadap modul pembelajaran tematik berbasis saintifik dengan penguatan karakter mandiri pada subtema perpindahan kalor yang dikembangkan yaitu menampilkan sumber gambar yang diambil dari internet.

Tabel 5. Hasil Validasi Ahli Materi

\begin{tabular}{|c|c|c|c|c|}
\hline No. & Aspek & Nilai & Persentase (\%) & Kategori \\
\hline A. & Penyajian Modul & & & \\
\hline 1. & Kelengkapan bagian modul & 4 & 100 & Sangat Valid \\
\hline 2. & Bagian awal modul & 4 & 100 & Sangat Valid \\
\hline 3. & Bagian inti modul & 4 & 100 & Sangat Valid \\
\hline 4. & Bagian akhir modul & 4 & 100 & Sangat Valid \\
\hline B. & Materi & & & \\
\hline 5. & Kesesuaian KD, tujuan, materi & 4 & 100 & Sangat Valid \\
\hline 6. & Kegiatan mengamati & 3 & 75 & Cukup Valid \\
\hline 7. & Kegiatan menanya & 3 & 75 & Cukup Valid \\
\hline 8. & Kegiatan mengumpulkan data & 3 & 75 & Cukup Valid \\
\hline 9. & Kegiatan mengolah data & 4 & 100 & Sangat Valid \\
\hline 10. & Kegiatan mengkomunikasikan & 4 & 100 & Sangat Valid \\
\hline 11. & Kegiatan praktikum & 3 & 75 & Cukup Valid \\
\hline \multirow[t]{3}{*}{12.} & Penguatan karakter mandiri & 4 & 100 & Sangat Valid \\
\hline & Jumlah & 28 & 700 & - \\
\hline & Rata-Rata & 3,5 & 87,5 & Sangat Valid \\
\hline C. & Karakteristik Modul & & & \\
\hline \multirow[t]{2}{*}{13.} & Self intructional (a) & 4 & 100 & Sangat Valid \\
\hline & Self intructional (b) & 4 & 100 & Sangat Valid \\
\hline 14. & Self contained & 4 & 100 & Sangat Valid \\
\hline 15. & Stand alone & 4 & 100 & Sangat Valid \\
\hline 16 & Adaptive & 3 & 75 & Cukup Valid \\
\hline \multirow[t]{6}{*}{17} & User friendly & 4 & 100 & Sangat Valid \\
\hline & Jumlah & 23 & 575 & - \\
\hline & Rata-Rata & 3,5 & 95,8 & Sangat Valid \\
\hline & Jumlah & 67 & 1675 & - \\
\hline & Rata-Rata & 3,7 & 93,05 & Sangat Valid \\
\hline & Keputusan Uji & Dapat & gunakan tanpa re & \\
\hline
\end{tabular}

Berdasarkan hasil validasi pada Tabel 5, didapatkan keputusan uji bahwa modul pembelajaran tematik berbasis saintifik dengan penguatan karakter mandiri pada subtema perpindahan kalor yang dikembangkan layak diujicobakan tanpa revisi. Komentar dan saran ahli materi terhadap modul pembelajaran tematik berbasis saintifik dengan penguatan karakter mandiri pada subtema perpindahan kalor yang dikembangkan yaitu (1) perlu adanya 
perbaikan pada konsep pengertian kalor; (2) memberikan urutan pada petunjuk penggunaan modul agar lebih mudah dipahami, (3) pada praktikum perpindahan kalor secara konduksi sebaiknya diberikan tabel untuk mempermudah dalam pengambilan data ketika praktikum; (4) kosakata dalam glosarium perlu ditambah, seperti pengertian kalor, konduksi, konveksi, dan radiasi

Tabel 6. Hasil Validasi Pengguna (Guru)

\begin{tabular}{|c|c|c|c|c|}
\hline No. & Aspek & Nilai & Persentase (\%) & Kategori \\
\hline A. & Penyajian Modul & & & \\
\hline 1. & Kelengkapan bagian modul & 4 & 100 & Sangat Valid \\
\hline 2. & Bagian awal modul & 4 & 100 & Sangat Valid \\
\hline 3. & Bagian inti modul & 4 & 100 & Sangat Valid \\
\hline 4. & Bagian akhir modul & 4 & 100 & Sangat Valid \\
\hline B. & Tampilan Modul & & & \\
\hline 5. & Konsistensi & 4 & 100 & Sangat Valid \\
\hline 6. & Format & 4 & 100 & Sangat Valid \\
\hline 7. & Organisasi & 4 & 100 & Sangat Valid \\
\hline 8. & Daya tarik & 4 & 100 & Sangat Valid \\
\hline 9. & Ukuran huruf & 4 & 100 & Sangat Valid \\
\hline 10. & Penggunaan spasi kosong & 4 & 100 & Sangat Valid \\
\hline B. & Materi & & & \\
\hline 11. & Kesesuaian KD, tujuan, materi & 4 & 100 & Sangat Valid \\
\hline 12. & Kegiatan mengamati & 4 & 100 & Sangat Valid \\
\hline 13. & Kegiatan menanya & 3 & 75 & Cukup Valid \\
\hline 14. & Kegiatan mengumpulkan data & 4 & 100 & Sangat Valid \\
\hline 15. & Kegiatan mengolah data & 4 & 100 & Sangat Valid \\
\hline 16. & Kegiatan mengkomunikasikan & 4 & 100 & Sangat Valid \\
\hline 17. & Kegiatan praktikum & 3 & 75 & Cukup Valid \\
\hline \multirow{3}{*}{18.} & Penguatan karakter mandiri & 3 & 75 & Cukup Valid \\
\hline & Jumlah & 29 & 725 & - \\
\hline & Rata-Rata & 3,6 & 90,6 & Sangat Valid \\
\hline C. & Karakteristik Modul & & & \\
\hline \multirow[t]{2}{*}{19.} & Self intructional (a) & 4 & 100 & Sangat Valid \\
\hline & Self intructional (b) & 4 & 100 & Sangat Valid \\
\hline 20. & Self contained & 4 & 100 & Sangat Valid \\
\hline 21. & Stand alone & 4 & 100 & Sangat Valid \\
\hline & Adaptive & 3 & 75 & Cukup Valid \\
\hline \multirow[t]{6}{*}{23.} & User friendly & 4 & 100 & Sangat Valid \\
\hline & Jumlah & 23 & 575 & - \\
\hline & Rata-Rata & 3,8 & 95,8 & Sangat Valid \\
\hline & Jumlah & 92 & 2300 & - \\
\hline & Rata-Rata & 3,8 & 95,8 & Sangat Valid \\
\hline & Keputusan Uji & Dap & gunakan tanpa $\mathrm{r}$ & \\
\hline
\end{tabular}

Komentar dan saran pengguna terhadap modul pembelajaran tematik berbasis saintifik dengan penguatan karakter mandiri pada subtema perpindahan kalor yang dikembangkan yang dipaparkan pada Tabel 6 yaitu (1) masih terdapat nomor halaman yang ganda; (2) dalam pertanyaan masih ditemukan kata-kata yang belum efektif; (3) beberapa petunjuk dalam praktikum kurang dapat dipahami. Berdasarkan hasil validasi, didapatkan keputusan uji bahwa modul pembelajaran tematik berbasis saintifik dengan penguatan karakter mandiri pada subtema perpindahan kalor yang dikembangkan layak diujicobakan tanpa 
revisi.Berdasarkan hasil validasi modul direvisi sesuai saran. Hasil dari revisi ditunjukkan pada Gambar 1 dan Gambar 2 berikut.
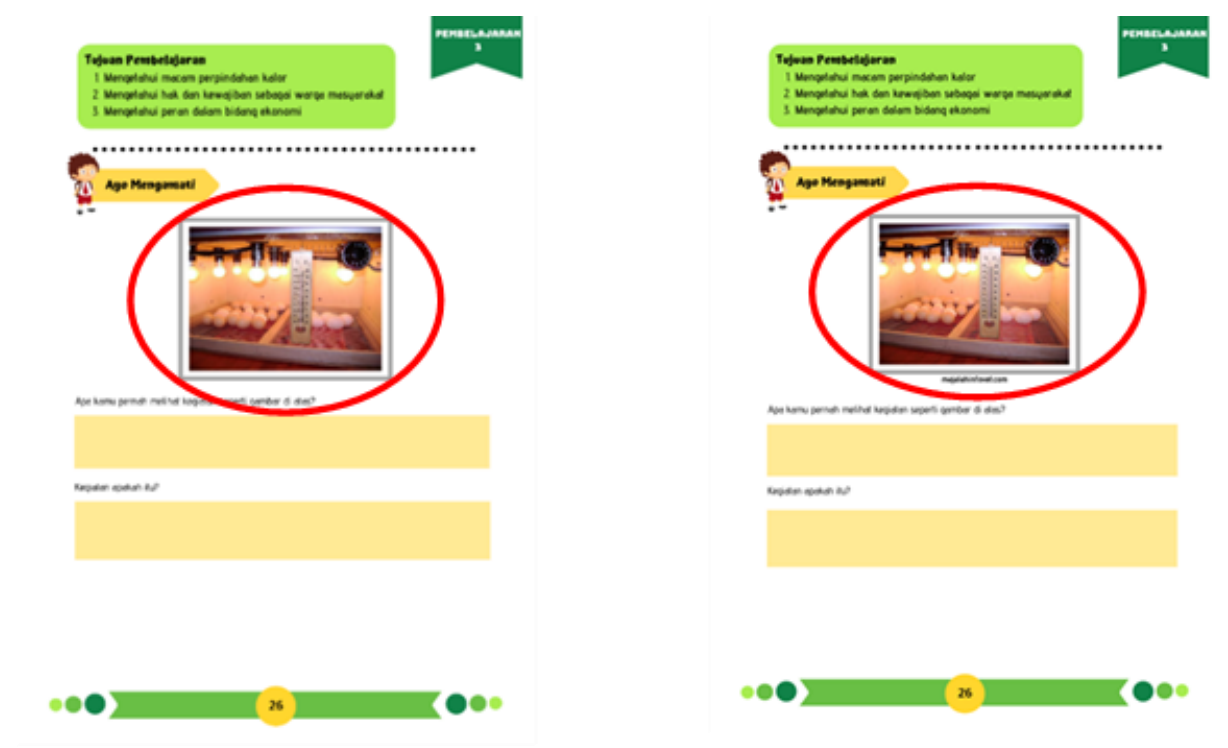

Gambar 1. Gambar dari internet sebelum direvisi (a) dan sesudah direvisi (b)

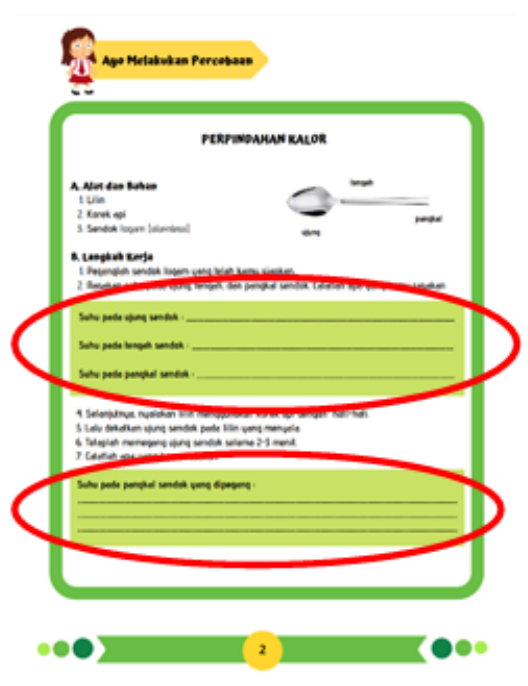

(a)

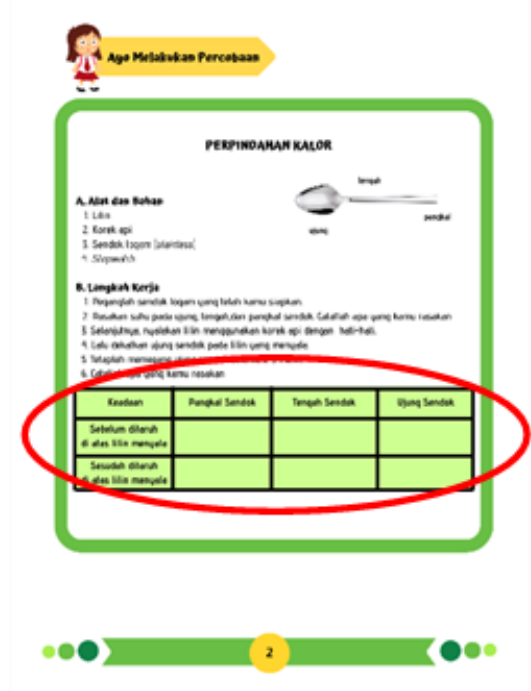

(b)

Gambar 2. Kegiatan praktikum Pembelajaran 1 sebelum direvisi (a) dan sesudah direvisi (b) 
Setelah divalidasi dan direvisi modul diujicobakan kepada siswa pada ujicoba 1 dalam skala kecil (ujicoba produk) dan ujicoba 2 dalam skala besar (ujicoba pemakaian). Pada ujicoba produk dilakukan kepada 6 siswa SDK YBPK Purworejo Wates Kediri dan ujicoba pemakaian dilakukan pada 32 siswa SDN Gadungan. Dalam ujicoba kepada siswa kali ini, siswa diberikan angket respon terhadap kemenarikan modul yang dikembangkan serta kemandirian belajar. Hasil respon siswa dalam ujicoba produk dan ujicoba pemakaian diakumulasikan dan dipaparkan dalam Tabel 7 berikut.

Tabel 7. Data Respon Siswa Terkait dengan Kemenarikan dan Kemandirian Tahap Ujicoba 1 dan Ujicoba 2

\begin{tabular}{|c|c|c|c|c|c|c|}
\hline \multirow[t]{2}{*}{ Aspek } & \multirow[t]{2}{*}{ No. } & \multirow[t]{2}{*}{ Pernyataan } & \multicolumn{4}{|c|}{ Respon Siswa } \\
\hline & & & $\begin{array}{l}\text { Uji } \\
\text { Coba } \\
1\end{array}$ & Persentase & $\begin{array}{l}\text { Uji } \\
\text { Coba } \\
2\end{array}$ & Persentase \\
\hline \multirow[t]{9}{*}{ Kemenarikan } & 1. & $\begin{array}{l}\text { Gambar yang } \\
\text { digunakan pada } \\
\text { sampul buku } \\
\text { membuatku ingin } \\
\text { membaca buku ini. }\end{array}$ & 6 & $100 \%$ & 32 & $100 \%$ \\
\hline & 2. & $\begin{array}{l}\text { Huruf yang } \\
\text { digunakan menarik } \\
\text { dan mudah untuk } \\
\text { aku baca. }\end{array}$ & 6 & $100 \%$ & 32 & $100 \%$ \\
\hline & 3. & $\begin{array}{l}\text { Ukuran huruf pada } \\
\text { buku tidak terlalu } \\
\text { besar dan tidak } \\
\text { terlalu kecil, aku } \\
\text { dapat membacanya } \\
\text { dengan mudah. }\end{array}$ & 6 & $100 \%$ & 32 & $100 \%$ \\
\hline & 4. & $\begin{array}{l}\text { Gambar yang } \\
\text { digunakan di dalam } \\
\text { buku ini sangat } \\
\text { menarik, aku jadi } \\
\text { mudah memahami. }\end{array}$ & 6 & $100 \%$ & 32 & $100 \%$ \\
\hline & 5. & $\begin{array}{l}\text { Buku ini berwarna } \\
\text { dan menarik untuk } \\
\text { aku baca }\end{array}$ & 6 & $100 \%$ & 32 & $100 \%$ \\
\hline & & Jumlah & 30 & $500 \%$ & 160 & $500 \%$ \\
\hline & & Rata-Rata & 6 & $100 \%$ & 32 & $100 \%$ \\
\hline & & Kategori & Sanga & lenarik & Sanga & Ienarik \\
\hline & & Keputusan Uji & \multicolumn{4}{|c|}{ Dapat digunakan tanpa revisi } \\
\hline \multirow[t]{3}{*}{ Kemandirian } & 6. & $\begin{array}{l}\text { Bahasa yang } \\
\text { digunakan dalam } \\
\text { buku ini mudah aku } \\
\text { pahami, aku jadi } \\
\text { bisa belajar secara } \\
\text { mandiri }\end{array}$ & 6 & $100 \%$ & 32 & $100 \%$ \\
\hline & 7. & $\begin{array}{l}\text { Aku dapat } \\
\text { mengerjakan soal- } \\
\text { soal di dalam buku } \\
\text { secara mandiri }\end{array}$ & 5 & $83,3 \%$ & 31 & $96,8 \%$ \\
\hline & 8. & $\begin{array}{l}\text { Apabila ada soal } \\
\text { yang sulit, saya } \\
\text { berusaha }\end{array}$ & 5 & $83,3 \%$ & 31 & $96,8 \%$ \\
\hline
\end{tabular}




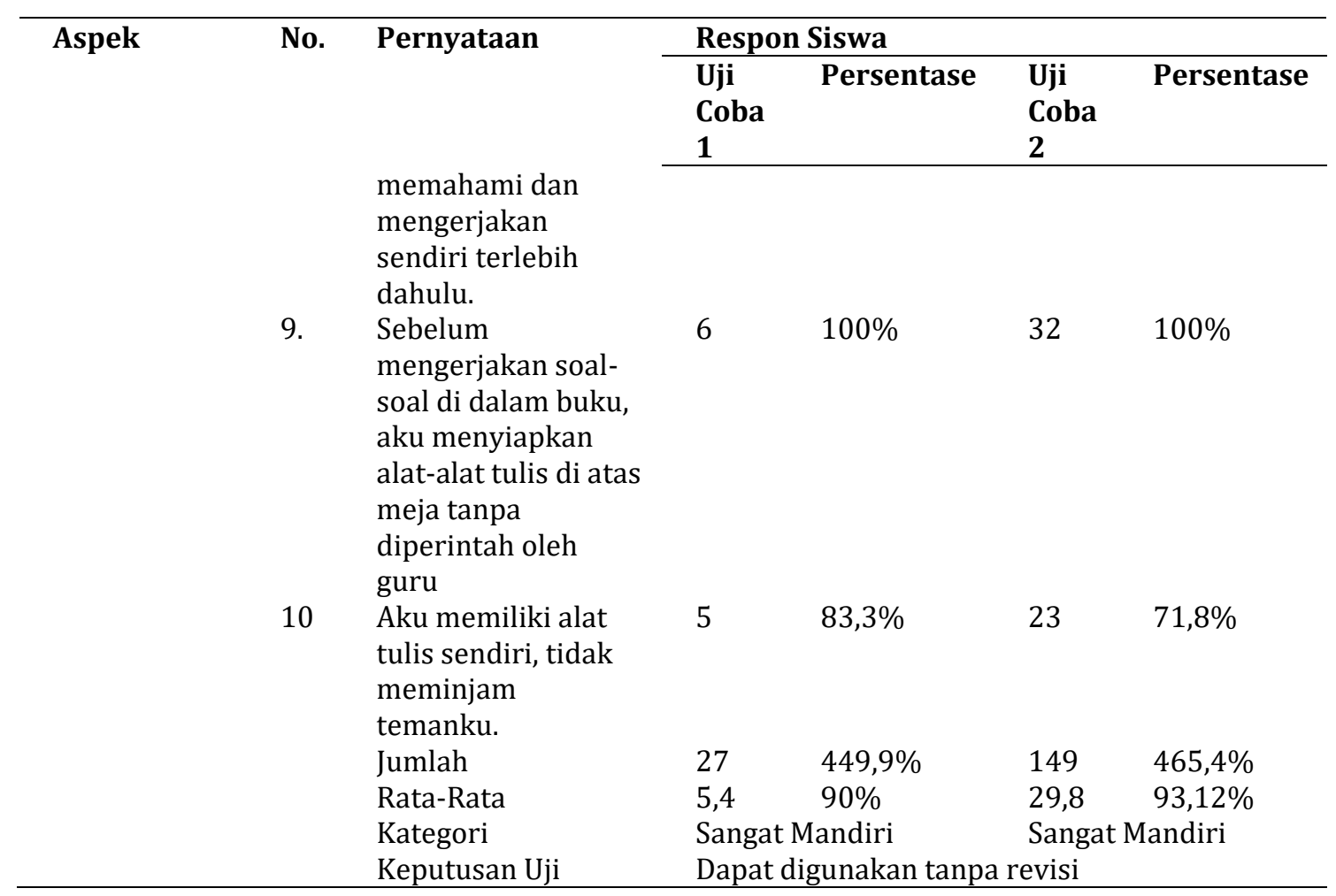

Berdasarkan tabel 7 di atas, keseluruhan aspek kemenarikan tampilan modul dikategorikan sangat menarik yang didapatkan dari haril ujicoba produk (Ujicoba 1) dan ujicoba pemakaian (ujicoba 2) dengan persentase 100\%. Keseluruhan aspek kemandirian siswa juga diperoleh kategori sangat mandiri. Namun pada ujicoba produk masih terdapat poin pernyataan yang mendapat respon "tidak" dari siswa yang artnya masih ada siswa yang belum mandiri. Sedangakan dalam ujicoba pemakaian aspek kemandirian 4 dari 5 poin dikategorikan sangat mandiri namun masih terdapat siswa yang merespon "tidak" pada poin yang berkaitan dengan soal dalam modul. Sedangkan 1 poin dikategorikan cukup mandiri dengan persentase 71,8\%, yang diketahui 9 dari 32 siswa masih belum memiliki alat tulis sendiri, sehingga kemandirian mereka dalam persiapan belajar masih dikategorikan cukup.

Setelah dilakukan ujicoba produk dan ujicoba pemakaian modul direvisi sesuai hasil ujicoba. Dalam tahap ini revisi dilakukan pada pembelajaran 1 pada alat percobaan yang mulanya menggunakan sendok logam diganti dengan paku, karena penggunaan sendok logam diniai terlalu memakan banyak waktu.

Tahap terakhir setelah revisi produk adalah produksi masal. Dalam pengembangan ini produksi masal hanya meproduksi empat modul sesuai dengan kebutuhan penelitian karena keterbatasan biaya. Hal tersebut juga didukung oleh pendapat Ardana (dalam Haryanto, Dwiyogo \& Sulistyorini, 2016) yang menjelaskan bahwa setiap pengembangan dapat memilih dan menentukan langkah-langkah sesuai kondisi yang dihadapi dalam proses pengembangan.

Kevalidan modul pembelajaran tematik berbasis saintifik dengan penguatan karakter mandiri dinilai dari aspek penyajian modul, tampilan modul, materi, serta kesesuaian dengan karakteristik modul. Aspek tampilan pada modul yang dikembangkan berdasarkan hasil validasi oleh ketiga validator, didapatkan hasil bahwa dalam modul sudah memenuhi kriteria 
penyajian modul. Dari ketiga validator penyajian modul mendapatkan kategori sangat baik dengan persentase 100\%. Menurut Prastowo (2016) modul setidaknya berisi tujuh komponen yaitu (a) judul; (b) petunjuk; (c) kompetensi yang akan dicapai; (d) informasi pendukung; (e) latihan; (f) lembar kerja; dan (g) evaluasi.

Aspek tampilan modul yang dikembangkan memperoleh kriteria sangat baik dari ahli bahan ajar dan pengguna dengan persentase 100\%. Format tampilan modul sudah sesuai mulai dari format tampilan kolom, format bidang pengetikan menggunakan kertas A4, serta icon yang digunakan sudah menekankan pada hal-hal yang penting. Modul memiliki daya tarik yang baik mulai dari tampilan sampul modul yang didesain dengan menggunakan Corel Draw $X 7$ dan disusun di aplikasi Canva. Bentuk huruf Advent Pro Medium yang digunakan mudah dibaca juga sudah sesuai dengan karakter siswa. Tampilan modul yang dikembangkan telah memenuhi enam elemen ketentuan penyusunan modul menurut Arsyad (dalam Nugraha, 2018) yaitu aspek konsistensi, kesesuaian format, kesesuaian pengorganisasian teks, gambar atau ilustrasi, penggunaan daya tarik dalam modul, kesesuaian penggunaan spasi, serta kesesuaian bentuk dan ukuran huruf

Aspek penyajian materi modul yang dikembangakan memperoleh kriteria sangat baik dari ahli materi dan pengguna dengan persentase masing-masing 87,5\% dan 90,6\%. Komptensi Dasar (KD), tujuan dan materi dalam modul yang dikembangkan sudah sesuai. Dalam pengimplementasian langkah pembelajaran saintifik sudah terdapat lima langkah pembelajaran yaitu mengamati gambar/ilustrasi, menanya, mengumpulkan data dengan melakukan percobaan, mengolah data, dan mengkomunikasikannya secara tertulis. Langkahlangkah tersebut sesuai dengan yang dikemukakan oleh Daryanto (2014) yaitu mengamati, menanya, menalar, mencoba dan mengkomunikasikan. Namun pada langkah pengumpulan data masih perlu dibenahi sesuai saran dari ahli materi. Langkah praktikum perpindahan kalor secara konduksi pada Pembelajaran 1 diubah dari yang semula pertanyaan-pertanyaan menjadi tabel yang memudahkan siswa untuk membandingkan hasil pengamatan. Selain itu, sesuai juga dengan hasil validasi dari pengguna (guru) dalam penguatan karakter mandiri mendapat kategori cukup baik, karena masih terdapat petunjuk-petunjuk yang kurang dipahami oleh siswa. Contohnya pada pembelajaran 3, dalam penugasan menjelaskan peran, hak, dan kewajiban orang-orang yang terlibat dalam peternakan ayam. Hendaknya dalam lembar jawaban diberikan bantuan menjawab dengan menuliskan "peran", "hak", "kewajiban" agar siswa mudah mengorganisasikannya.

Aspek kesesuaian dengan karakteristik modul secara keseluruhan menurut hasil validasi oleh ahli materi, ahli bahan ajar, dan pengguna mendapatkan katergori sangat baik dengan persentase masing-masing 95,8\%, 100\%, dan 95,8\%. Pada aspek ini yang dinilai adalah dari enam segi menurut Direktorat Jendral PMPTK (2008) yaitu dapat digunakan sendiri (self intructional), dipelajari secara utuh (self contained), tidak memerlukan bantuan media lain (stand alone), sesuai perkembangan zaman (adaptive), dan mudah digunakan (user friendly). Namun dari aspek adaptive, modul yang dikembangkan belum mengikuti perkembangan teknologi yang ada.

Hasil respon siswa kedua ujicoba yang dilakukan, modul yang dikembangkan sudah menarik untuk digunakan oleh siswa. Modul sudah menggunakan gambar dan ilustrasi yang menarik baik dari sampulnya maupun isinya. Huruf yang digunakan juga menarik dan mudah dibaca. Hal tersebut dapat membuat siswa tertarik untuk belajar menggunakan modul yang 
telah dikembangkan. Seperti yang dikemukakan oleh Gafur (2003) bahwa penggunaan desain gambar, ilustrasi, bagan dan warna yang menarik juga dapat digunakan sebagai alat pemusat perhatian untuk siswa. Dari aspek kemandirian dilihat dari rata-rata kedua ujicoba modul sudah dapat digunakan secara mandiri oleh siswa. Namun dalam kedua ujicoba didapatkan data bahwa ada beberapa siswa yang belum dapat memahami soal serta berusaha mengerjakannya secara mandiri terlebih dahulu, selain itu masih banyak siswa yang belum menyiapkan alat tulisnya secara mandiri sebelum pembelajatran dimulai. Sehingga perlu adanya pengembangan karakter tanggung jawab dan percaya diri. Hal tersebut sesuai dengan pendapat yang dikemukakan oleh Widodo, R. D., Pramudita, P. T., Nurfitasari, Y., \& Salimi, M. (2016) sikap mandiri meliputi sikap kreatif, percaya diri dan puas dengan hasil pekerjaannya, serta tanggung jawab. Sikap kreatif dilihat dari kemampan dalam mencari sumber belajar untuk menyelesaikan tugasnya. Sikap percaya diri dilihat dari siswa yang puas dengan hasil kerjanya dan tidak tergantung dengan bantuan temannya. Sikap tanggung jawab dilihat dari menyelesaikan tugas-tugas yang diberikan, menyiapkan peralatan yang akan digunakan dalam pembelajaran dengan inisiatif sendiri.

\section{Simpulan}

Berdasarkan hasil pembahasan disimpulkan bahwa Modul Pembelajaran Tematik Berbasis Saintifik dengan Penguatan Karakter Mandiri Pada Subtema Perpindahan Kalor di Kelas V SDN Gadungan Wates Kabupaten Kediri ini memperoleh hasil validasi 93,05\% dengan kategori "sangat valid" dari ahli materi dari aspek penyajian modul, materi modul, dan kesesuaian dengan karakteristik modul. Sedangkan hasil dari validasi oleh ahli bahan ajar mendapatkan persentase $100 \%$ dengan kategori "sangat valid" yang dinilai dari aspek penyajian modul, tampilan, dan kesesuaian dengan karakteristik modul. Dan dari pengguna mendapatkan hasil validasi 95,8\% dengan kategori "sangat valid" yang dinilai dari aspek penyajian modul, tampilan modul, materi, serta kesesuaian dengan karakteristik modul. Kemenarikan modul juga dinyatakan "sangat menarik" sesuai dengan hasil validasi ahli bahan ajar dan pengguna dengan persentase $100 \%$. Selain itu kemenarikan juga dinilai dari respon siswa SDN Gadungan Wates Kabupaten Kediri yang mendapatkan persentase 100\% dengan kategori "sangat menarik". Sebelum diujicobakan produk ini sudah direvisi sesuai dengan saran dan komentar para ahli/validator. Dari data yang dipaparkan dapat disimpulkan bahwa modul Modul Pembelajaran Tematik Berbasis Saintifik dengan Penguatan Karakter Mandiri Pada Subtema Perpindahan Kalor layak dan menarik untuk digunakan di Kelas V SDN Gadungan Wates Kabupaten Kediri.

\section{Daftar Rujukan}

Akbar, S. (2015). Instrumen Perangkat Pembelajaran. Bandung : PT Remaja Rosdakarya.

Daryanto. (2014). Pendekatan Pembelajaran Saintifik Kurikulum 2013. Yogyakarta: Penerbit Gaya Media.

Direktorat Jenderal Peningkatan Mutu Pendidik dan Tenaga Kependidikan. (2008). Penulisan Modul. Jakarta: Kementerian Pendidikan dan Kebudayaan.

Gafur, A. (2003). Penerapan Konsep dan Prinsip Pembelajaran Kontekstual (Contextual Teaching And Learning) dan Desain Pesan dalam Pengembangan Pembelajaran dan Bahan Ajar. Cakrawala Pendidikan, 22(3), 273-289.

Haryanto, T. S., Dwiyogo, W. D., \& Sulistyorini, S. (2016). Pengembangan Pembelajaran Permainan Bolavoli Menggunakan Media Interaktif di SMP Negeri 6 Kabupaten Situbondo. Jurnal Pendidikan Jasmani, 25(1), 123-128.

Kemendikbud. (2016). Peraturan Menteri Pendidikan Dan Kebudayaan Nomor 22 Tahun 2016 tentang Standar Proses Pendidikan Dasar Dan Menengah. Jakarta: Kemendikbud. 
Jurnal Pembelajaran, Bimbingan, dan Pengelolaan Pendidikan, 1(4), 2021, 269-279

Nugraha, A. S. (2018). Pengembangan Modul Pemesinan Bubut Kelas XI Jurusan Teknik Pemesinan SMK Negeri 2 Klaten. Jurnal Pendidikan Vokasional Teknik Mesin, 6(3), 213-220.

Oktaviyani, F. (2016). Pengembangan Modul IPA Berbasis Kemandirian Belajar Siswa Kelas IV SD. Doctoral dissertation. Universitas Negeri Jakarta.

Prastowo, A. (2016). Pengembangan Bahan Ajar Tematik. Jakarta: Kencana.

Sugiyono. (2014). Metode Penelitian Pendidikan: Pendekatan Kuantitatif, Kualitatif, dan R\&D. Bandung: Alfabeta.

Widodo, R. D., Pramudita, P. T., Nurfitasari, Y., \& Salimi, M. (2016). Pembelajaran VAK untuk Mengembangkan Nilai Mandiri dan Kreatif pada Siswa SD : Sebuah Kajian Awal. In Prosiding Seminar Nasional Inovasi Pendidikan. 